\title{
Response of Wavyleaf Oak to Nitrogen Fertilization
}

\author{
VOLNEY W. HOWARD, JR., JERRY R. COX, AND G. MORRIS SOUTHWARD
}

\begin{abstract}
This study was conducted to determine the response of wavyleaf oak to nitrogen fertilization, at rates of 0,112 , and $224 \mathrm{~kg}$ of elemental nitrogen per ha. Over the three years of the study, twigs were longer on fertilized areas than on unfertilized areas. Nitrogen at $112 \mathrm{~kg} / \mathrm{ha}$ was generally as effective as $224 \mathrm{~kg} / \mathrm{ha}$ in stimulating twig growth. Slope position did not have an effect on all sites. Where slope position was significant, plants on the upper and middle slopes responded better to fertilization than did plants growing on lower slopes. Site appeared to influence twig growth more than slope. Differences in twig growth among sites were attributed to differences in soil depth and density of vegetation. Twig length was significantly different among years due to uneven distribution of rainfall.
\end{abstract}

As wildlife populations are restricted to less favorable areas, it is increasingly important to develop new and better methods of habitat manipulation. One important area involves improvement of quality and quantity of food, as demonstrated in several studies of mule deer (Odocoileus hemionus) and white-tail deer (O. virginianus). Deer densities can be controlled by quantity and nutritive quality of available forage (Hagen 1953, Swank 1956). Many deer diseases are due to inadequate nutrition (Lang 1957, Taylor and Hahn 1947), and fertility levels in deer generally correspond with the quality of their range (Cheatum and Severinghaus 1950, Julander et al. 1961).

Recently, fertilization has gained importance in improvement of wildlife ranges. Williams (1969) stated that soil fertilization may be valuable in correcting nutritional deficiencies occurring within a wild population, providing the deficiencies are properly diagnosed and fertilizers are administered accordingly. Fertilization can significantly increase production of range plants (Schultz et al. 1958) and substantially increase carrying capacity of the range (Ward and Bowersox 1970). Fertilization can cause major compositional changes in vegetation (Basile 1970, Gibbens and Pieper 1962, Schultz et al. 1958), improve the palatability of certain species (Brown and Mandery 1962, Gibbens and Pieper 1962, Schultz et al. 1958), and improve the quality of forage (Rogler and Lorenz 1957, Ward and Bowersox 1970, Wood 1966).

On the Fort Stanton Cooperative Experimental Range, Anderson et al. (1974) fertilized mountain mahogany (Cercocarpus montanus) and wavyleaf oak (Quercus undulata) with urea at the rate of $101 \mathrm{~kg}$ nitrogen $(\mathrm{N}) /$ ha. The moun-

\footnotetext{
Authors are professor, Department of Fishery and Wildlife Sciences, New Mexico State University, Las Cruces 88003; research scientist USDA, Rangelands Weed and Brush Control, Tucson, Arizona 85719; and professor, Department of Experimental Statistics New Mexico State University, Las Cruces, New Mexico 88003

This study was supported by the New Mexico Agricultural Experiment Station and McIntire-Stennis funds. Nipak, Inc., Dallas, Texas donated the fertilizer for this project.

This Journal Article 681, Agricultural Expcriment Station, New Mexico Statc University, Las Cruces, New Mexico 88003.

Manuscript received August 7, 1978.
}

tain mahogany showed a growth response to the fertilizer, and the percent crude protein in leaves of wavyleaf oak increased. Mule deer use was greater on fertilized plots than on control plots.

Since oak constitutes a major portion of mule deer diets in the Southwest (Anderson et al. 1965, Boeker et al. 1972, Lamb 1971, Smith 1959), this study was initiated to determine growth response of wavyleaf oak to different rates of fertilization in a pinyon-juniper woodland.

\section{Methods}

Fort Stanton Cooperative Experimental Range encompasses 10,522 ha in Lincoln County in south-central New Mexico. Topography consists of mesas and rolling hills situated between deep, rocky canyons. Shrubs and trees are located on the slopes. Grasslands are found on mesa tops, canyon floors, and lowlands (Groce and Pieper 1967). The soils are shallow and have a stony loam texture. They are deficient in $\mathrm{N}$ but are not lacking in potassium or phosphorus (USDA, Soil Conservation Service 1966).

The climate is mild with warm summers and cool to cold winters. The mean annual temperature is $11^{\circ} \mathrm{C}$, reaching a mean summer maximum of $19^{\circ} \mathrm{C}$ and a mean winter minimum of $-7^{\circ} \mathrm{C}$. The 94-year average annual precipitation is $384 \mathrm{~mm}$. Approximately $60 \%$ of the precipitation occurs between June and September (Pieper et al. 1973).

The Experimental Range is in the Upper Sonoran Life Zone (Bailey 1913). Dominant woody species in the area are pinyon pine (Pinus edulis), single-seed juniper (Juniperus monosperma), alligator juniper (J. depeana), and wavyleaf oak (Anderson et al. 1974). The dominant grass is blue grama (Bouteloua gracilis)(Groce and Pieper 1967). Wavyleaf oak is located in dense stands on rocky, steep slopes with pinyon and juniper scattered intermittently throughout.

Four deer-and cattle-proof exclosures (replications) were constructed in the summer of 1971. These exclosures were located on northwest slopes with similar soil types and slopes. The experimental design was $3 \times 3$ factorial set of treatments in a randomized split-plot with four replications. The treatments consisted of three slope positions (main plots) and three $\mathrm{N}$ rates (sub-plots) (Fig. 1). The main plots were separated by buffer zones to prevent runoff from contaminating plots further downhill. Sub-plots were large enough to include ten or more wavyleaf oak plants. Fertilizer was broadcast in June 1972 at the rates of 0,112 , and $224 \mathrm{~kg} \mathrm{~N} / \mathrm{ha}(0$, 100 , and $200 \mathrm{lb} \mathrm{N} /$ acre).

Response to these treatments was determined by measuring annual twig growth in winter after leaf-fall.

Analyses of variance were performed on the means of apical twig length and diameter. The analyses examined differences due to $\mathrm{N}$ rates, sites, slopes, years, and interactions between these factors. Those factors having significant $F$ values $(P<.10)$ were tested by the least significant difference (lsd) procedure (Steel and Torrie 1960).

On each sub-plot of the four exclosures, ten wavyleaf oak plants were selected and one twig from each plant was tagged with plasticcovered electrical wiring, so measurements of the same twigs could 


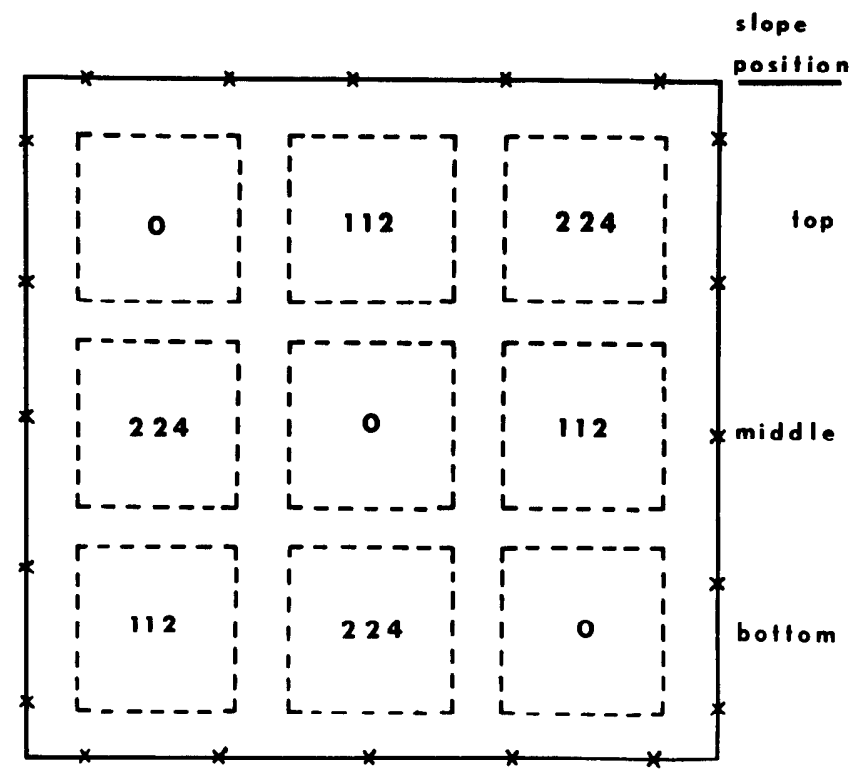

Fig. 1. An illustration of the relationships between rates $(\mathrm{kg} / \mathrm{ha})$ of $\mathrm{N}$ fertilizer treatments, slope positions, and buffer zones.

be made in successive years (Gibbens and Pieper 1962).

Measurements of apical twig lengths and diameters were taken from each tagged twig in the winters of 1972, 1973, and 1974. Measurements were made to the nearest $0.1 \mathrm{~mm}$ with Vernier calipers. Measurements of twig lengths included terminal buds. Diameters were measured at the base of the new growth for each year. If node swelling occurred, twig diameter was measured immediately above the swelling (Basile and Hutchings 1966).

\section{Results and Discussion}

Analysis of variance of twig diameters showed excessive variability in the data and further statistical analysis was impractical. The remainder of this paper's reports on data from apical twig lengths.

Analysis of variance for twig length on all sites for all years showed a significant $(P<.1)$ response to $\mathrm{N}$-treatments. There also was a significant $(P<.005)$ difference between years following the application of $\mathrm{N}$-treatments. Variability among sites was high, but was not significant (Table 1).

A single application of $\mathrm{N}$, either 112 or $224 \mathrm{~kg} / \mathrm{ha}$, increased mean twig lengths for the following three years. However, $112 \mathrm{~kg} /$ ha N-fertilization was more effective than $224 \mathrm{~kg} / \mathrm{ha} \mathrm{N}$-fertilization on all sites except Site 4 (Table 2). It is possible that the lack of response to $112 \mathrm{~kg} / \mathrm{ha} \mathrm{N}$ fertilization on Site 4 was related to the density of the vegetation. Site 4 had more trees, smaller plants (in dense stands), and fewer open areas. Litter produced under dense
Table 1. Analysis of variance of twig lengths ( $\mathrm{mm}$ ) of wavyleaf oak on all sites in 1972, and 1973, and 1974.

\begin{tabular}{|c|c|c|c|c|}
\hline Source of variation & df & Sums of squares & $F$ values & $\begin{array}{c}\text { Proba- } \\
\text { bility }\end{array}$ \\
\hline Total & 107 & 23581.0970 & & \\
\hline Site & 3 & 2496.6256 & 2.55 & ns \\
\hline Slope & 2 & 324.0890 & 0.50 & ns \\
\hline Error A & 6 & 1960.1229 & & \\
\hline Fertilizer & 2 & 995.7461 & 3.22 & $.1<P<.05$ \\
\hline Slope $\times$ Fertilizer & 4 & 595.1262 & 0.96 & ns \\
\hline Error B & 18 & 2785.9492 & & \\
\hline \multirow[t]{2}{*}{ Year } & 2 & 5251.0094 & 20.06 & \\
\hline & & & \multicolumn{2}{|c|}{$.005<P<.001$} \\
\hline Slope $\times$ Year & 4 & 678.3115 & 1.30 & ns \\
\hline Fertilizer $\times$ Year & 4 & 340.6551 & 0.65 & ns \\
\hline $\begin{array}{l}\text { Slope } \times \text { Fertilizer } \times \\
\text { Year }\end{array}$ & 8 & 1084.7699 & 1.04 & ns \\
\hline Error C & 54 & 7068.6920 & & \\
\hline
\end{tabular}

stands often reduces the amount of precipitation infiltrating the soil and thus increases runoff (Gifford 1970).

Differences in growth response between years on all sites appeared to be related to precipitation. Gibbens and Pieper (1962) stated that the magnitude of growth response to fertilizer treatments undoubtedly would be greater in years of high rainfall.

During this study, precipitation was recorded at three locations in close proximity to the study sites (Table 3 ). Total precipitation was greater in 1972 and 1973. However, only $2 \%$ of the precipitation which occurred in 1972 fell early in the growing season. On all sites, no precipitation occurred in March and April of 1972, and less than 2\% occurred in May. In 1973 and 1974, 20 to $25 \%$ of the annual precipitation occurred in March, April, and May. There also was a carry-over of soil moisture from the winters preceding the 1973 and 1974 growing seasons.

Although the middle slope-position produced greater mean twig lengths on Sites 2, 3, and 4 (Table 2), these differences were not large enough to be significant (Table 1). Apparently slope-position was not an important factor in the plants' ability to respond to $\mathrm{N}$-fertilization. However, plants on the upper two-thirds of the slopes appeared to have a greater response to $\mathrm{N}$-fertilization than did those located on the lower one-third (Table 2).

\section{Conclusions}

Nitrogen fertilization significantly increased twig growth of wavyleaf oak on the Fort Stanton Cooperative Experimental Range. Nitrogen fertilization can be an effective management tool, providing the management area receives

Table 2. Means of twig lengths, in mm, for years, slopes, and N-treatments for all sites.

\begin{tabular}{|c|c|c|c|c|c|c|c|c|c|}
\hline \multirow[b]{2}{*}{ Sites } & \multicolumn{3}{|c|}{ Years } & \multicolumn{3}{|c|}{ Slopes } & \multicolumn{3}{|c|}{ Treatments (kg/ha) } \\
\hline & 1972 & 1973 & 1974 & Top & Middle & Bottom & 0 & 112 & 224 \\
\hline 1 & 41.76 & 50.07 & 44.00 & 43.64 & 40.57 & 51.62 & $36.28^{4}$ & 50.28 & 49.26 \\
\hline 2 & 27.291 & 47.75 & 45.31 & 35.54 & $48.35^{2}$ & 36.46 & 33.18 & $51.96^{5}$ & 35.20 \\
\hline 3 & $23.82^{1}$ & 49.57 & 44.45 & 38.98 & 45.64 & 33.22 & 41.72 & 42.02 & 34.10 \\
\hline 4 & $21.10^{1}$ & 41.22 & 33.76 & 33.39 & 38.67 & $24.03^{3}$ & 25.88 & 33.37 & $36.83^{6}$ \\
\hline
\end{tabular}

\footnotetext{
ISignificant differences from 1973 and 1974
}

2Significant difference from top and bottom slopes

${ }^{3}$ Significant difference from top and middle slopes

${ }^{4}$ Significant differences from 112 and $224 \mathrm{~kg} / \mathrm{ha}$

'Significant difference from 0 and $224 \mathrm{~kg} / \mathrm{ha}$

'Significant difference from $0 \mathrm{~kg} / \mathrm{ha}$ 
Table 3. Monthly and total precipitation (mm) at three locations on the Fort Stanton Cooperative Experimental Range during 1972,1973 , and 1974.

\begin{tabular}{|c|c|c|c|c|c|c|c|c|c|}
\hline \multirow[b]{2}{*}{ Month } & \multicolumn{3}{|c|}{ West Mesa ${ }^{1}$} & \multicolumn{3}{|c|}{ Bonita Creek ${ }^{2}$} & \multicolumn{3}{|c|}{ High Mesa ${ }^{3}$} \\
\hline & 1972 & 1973 & 1974 & 1972 & 1973 & 1974 & 1972 & 1973 & 1974 \\
\hline January & 13.97 & 25.91 & 22.10 & 12.95 & 34.29 & 18.54 & 24.38 & 36.32 & 25.15 \\
\hline February & 6.60 & 42.16 & 13.97 & 4.06 & 36.32 & 9.91 & 9.40 & 45.97 & 12.95 \\
\hline March & 0 & 23.62 & 10.41 & 0 & 26.67 & 9.40 & 0 & 34.54 & 11.43 \\
\hline April & 0 & 17.78 & 2.03 & 0 & 17.78 & 3.05 & 0 & 23.37 & 5.08 \\
\hline May & 9.91 & 27.43 & .76 & 8.13 & 30.48 & 1.02 & 6.10 & 34.54 & 4.32 \\
\hline June & 95.50 & 20.07 & 1.27 & 76.54 & 26.16 & 1.27 & 72.39 & 28.19 & 2.79 \\
\hline July & 87.63 & 33.53 & 45.72 & 80.77 & 65.02 & 56.39 & 78.23 & 59.44 & 82.55 \\
\hline August & 99.31 & 53.34 & 160.78 & 155.70 & 59.18 & 63.50 & 135.64 & 43.69 & 118.87 \\
\hline September & 66.04 & 36.07 & 99.57 & 72.64 & 59.68 & 99.82 & 96.77 & 33.27 & 131.06 \\
\hline October & 101.85 & 1.52 & 104.14 & 86.61 & .21 & 98.04 & 85.09 & .51 & 100.08 \\
\hline November & 7.37 & 6.86 & 15.24 & 5.08 & 6.86 & 14.22 & 4.83 & 9.14 & 15.24 \\
\hline December & 11.18 & 0 & 30.99 & 12.70 & 0 & 28.96 & 15.75 & 0 & 34.54 \\
\hline Totals & 499.36 & 288.29 & 506.98 & 515.18 & 362.65 & 404.12 & 528.58 & 348.98 & 544.06 \\
\hline $\begin{array}{l}\text { Totals } \\
\text { (June-September) }\end{array}$ & 348.48 & 143.01 & 307.34 & 385.65 & 210.04 & 220.98 & 383.03 & 164.59 & 335.27 \\
\hline
\end{tabular}

Sites 1 and 2

${ }^{2}$ Site 3

3Site 4

adequate rainfall. On large operations, cost of fertilization could be limiting; therefore, treatments should be restricted to areas where they will achieve the best results.

This study indicated that $112 \mathrm{~kg} /$ ha $\mathrm{N}$ was as effective as $224 \mathrm{~kg} / \mathrm{ha}$. Two of the four sites showed greater growth response to $\mathbf{N}$ on the upper two-thirds of the slope. Deer use of fertilized browse on the Fort Stanton Cooperative Experimental Range is greatest on the upper three-fourths of the slope (Anderson et al. 1974). Thus, effectiveness of fertilization can be maximized, while the cost is minimized, if application is restricted to the upper slopes.

\section{Literature Cited}

Anderson, A.E., W.A. Snyder, and G.W. Brown. 1965. Stomach content analysis related to conditions in mule deer. Guadalupe Mountains, New Mexico. J. Wildl. Manage. 29: 352-366.

Anderson, B.L., R.D. Pieper, and V.W. Howard, Jr. 1974. Growth response and deer utilization of fertilized browse. J. Wildl. Manage. 38: 525-530.

Basile, J.V. 1970. Fertilizing to improve elk winter range in Montana. U.S. Dep. Agr. Forest Serv. Res. Note. No. 113.6 p.

Basile, J.V., and S.S. Hutchings. 1966. Twig diameter-length-weight relationships of bitterbrush. J. Range Manage. 19: 34-38.

Boeker, E. L., V.E. Scott, H.G. Reynolds, and B.A. Donaldson. 1972. Seasonal food habits of mule deer in southwestern New Mexico. J. Wildl. Manage. 36: 56-63.

Brown, R.E., and J.H. Mandery. 1962. Planting and fertilization as a possible means of controlling distribution of big game animals. J. Forest. 60: 33-35.

Cheatum, E.L., and C.W. Severinghaus. 1950. Variations in fertility of white-tail deer related to range conditions. Trans. N. Amer. Wildl. Conf. 15: $170-190$.
Gibbens, R.P., and R.D. Pieper. 1962. The response of browse plants to fertilization. California Fish and Game 48: 268-281.

Gifford, G.F. 1970. Some water movement patterns over and through pinyon-juniper litter. J. Range Manage. 23: 365-366.

Groce, V.L., and R.D. Pieper. 1967. Cover, herbage production and botanical composition on foothill range sites in southcentral New Mexico. Agr. Exp. Sta. Res. Rep. New Mexico State Univ., Las Cruces. 128 p.

Hagen, H.L. 1953. Nutritive value for deer of some forage plants in the Sierra Nevada. California Fish and Game. 29: 163-172.

Julander, O., W.L. Robinette, and D.A. Jones. 1961. Relation of summer range condition to mule deer herd productivity. J. Wildl. Manage. 25: 54-60.

Lamb, S.H. 1971. Woody plants of New Mexico and their value to wildlife Bull. 14. New Mexico Dep. Game and Fish, Santa Fe. 80 p.

Lang, E.M. 1957. Deer of New Mexico. Bull No. 5. New Mexico Dep. Game and Fish, Santa Fe. 41 p.

Pieper, R.D., D.D. Dwyer, and W.W. Wile. 1973. Burning and fertilizing bluegrama range in southcentral New Mexico, New Mex. State Univ. Agr. Exp. Sta. Bull. 611. 21 p.

Tucker, J.M. 1961. Studies in the Quercus undulata complex. (1) A preliminary statement. Amer. J. Bot. 48: 202-208.

U.S. Dep. Agr. Soil Conservation Service. 1966. Fort Stanton soil survey report. Roswell, New Mexico. Mimeo.

Ward, W.W. and T.W. Bowersox. 1970. Upland oak response to fertilization with nitrogen, phosphorus, and calcium. Forest Sci. 16: 113-120.

Williams, G.L. 1969. Effects of fertilizers on the nutritional quality of wildlife foods-a literature review. p. 14-17 In: Bailey, J.A., and J.G. Nagy, eds. Recent advances in wildlife nutrition, papers from a graduate seminar in wildlife biology. Colorado State Univ., Fort Collins.

Wood, G.W. 1966. The effects of forest fertilization on the crude protein, calcium, and phosphorus content of deer browse in a mixed oak forest. Nature Can. 94: 335-346. 